\begin{tabular}{l|l} 
Potaice & e-ISSN: 2655-9404 \\
Vol. 01 No. 2, Oktober 2018 & DOI: $10.20473 /$ ntr.v1i2.9602 \\
\hline
\end{tabular}

Article history: Submitted 3 October 2018; Accepted 10 October 2018; Available online 15 October 2018.

\title{
Kebijakan Hak Atas Tanah Untuk Rumah Tinggal Bagi Orang Asing
}

\author{
Noer Sida \\ noersidaa@gmail.com \\ Universitas Airlangga
}

\begin{abstract}
The population in Indonesia is not only an Indonesian citizen but also there are foreigners who reside in Indonesia with various backgrounds and reasons. The presence of foreigners certainly requires a residence to shelter in Indonesia. Because of that a policy is needed to provide legal certainty as well as the ease of providing services and permits to obtain land rights for foreigners. The purpose of this study is to analyze policies related to the rights of foreigners to own homes in Indonesia, through a normative juridical approach that is based on laws and regulations in force Government Regulation Number 103 of 2015 concerning Residential or Residential Houses by Foreigners Domiciled in Indonesia and Regulations Minister of Agrarian and Spatial Planning / Head of National Land Agency Number 29 of 2016 concerning Procedures for Granting, Releasing, or Transferring Rights to Ownership of Residential or Residential Houses by Foreigners Domiciled in Indonesia and also using comparative legal approaches of several ASEAN countries related to people's rights foreigners have land rights. The results of the research show that it is permissible for foreigners to have a residence on land of usufructuary rights in Indonesia with various requirements and restrictions, the same thing is also applied by the majority of other ASEAN countries.
\end{abstract}

Keywords: Land Rights; The Land Use; Single House; Foreigner.

\begin{abstract}
Abstrak
Penduduk yang berada di Indonesia tidak hanya warga negara Indonesia akan tetapi juga terdapat orang asing yang bertempat tinggal di Indonesia dengan berbagai latar belakang dan alasan. Keberadaan orang asing tersebut tentunya memerlukan rumah tempat tinggal atau hunian untuk bernaung selama di Indonesia.Sehingga diperlukan kebijakan yang memberikan kepastian hukum serta kemudahan dalam pemberian pelayanan maupun izin meperoleh hak atas tanah untuk rumah tempat tinggal atau hunian bagi orang asing.Tujuan penelitian ini adalah menganalisa kebijakan terkait hak orang asing memiliki rumah tinggal di Indonesia, melalui pendekatan yuridis normatif yaitu berdasarkan peraturan perundang-undangan yang berlaku Peraturan Pemerintah Nomor 103 Tahun 2015 tentang Pemilikan Rumah Tempat Tinggal atau Hunian oleh Orang Asing yang Berkedudukan di Indonesia dan Peraturan Menteri Agraria dan Tata Ruang/Kepala Badan Pertanahan Nasional Nomor 29 Tahun 2016 tentang Tata Cara Pemberian, Pelepasan, atau Pengalihan Hak Atas Pemilikan Rumah Tempat Tinggal atau Hunian oleh Orang Asing yang Berkedudukan di Indonesia dan juga menggunakan pendekatan perbandingan hukum beberapa negara ASEAN terkait hak orang asing memiliki rumah tinggal. Hasil penelitian menunjukkan bahwa diperkenankan bagi orang asing untuk memiliki rumah tinggal di atas tanah hak pakai di Indonesia dengan berbagai persyaratan dan pembatasan, hal serupa juga diterapkan oleh mayoritas negara ASEAN yang lain.
\end{abstract}

Kata Kunci: Hak atas Tanah; Hak Pakai; Rumah Tinggal; Orang Asing.

\section{Pendahuluan}

Hubungan hukum antara manusia dengan tanah sangatlah kuat karena 
hubungan tersebut bersifat abadi.Bahkan tanah menjadi kebutuhan dasar mansuia, sejak lahir manusia membutuhkan tanah untuk berbagai kebutuhan baik untuk keperluan tempat tinggal, usaha pertanian dan lain-lain. ${ }^{1}$ Tidak terkecuali Indonesia yang terkenal sebagai Negara agraris, ${ }^{2}$ oleh karena kedudukan tanah dalam pembangunan nasional ternyata dari Ketetapan Majelis Permusyawaratan Rakyat Republik Indonesia Nomor: II/MPR/1993 tentang Garis-garis Besar Haluan Negara yang antara lain memberi amanat sebagai berikut, "Penataan penguasaan tanah oleh negara diarahkan pemanfaatannya dapat mewujudkan keadilan sosial bagi seluruh rakyat Indonesia, sedangkan penataan penggunaan tanah dilaksanakan secara berencana guna mewujudkan kemakmuran rakyat yang sebesar-besarnya. Penataan penggunaan tanah perlu memperhatikan hakhak rakyat atas tanah, fungsi sosial hak atas tanah, batas maksimum pemilikan tanah, termasuk berbagai upaya untuk mencegah pemusatan penguasaan tanah yang merugikan kepentingan rakyat. Kelembagaan pertanahan disempurnakan agar makin terwujud sistem pengelolaan pertanahan yang terpadu, serasi, efektif, efisien, yang meliputi tertib administrasi hidup.Kegiatan pengembangan administrasi pertanahan perlu ditigkatkan dan ditunjang dengan perangkat analisis dan perangkat informasi pertanahan yang makin baik."

Ketetapan tersebut sejalan dengan tujuan yang ditegaskan dalam Pasal 33 ayat (3) UUD RI Tahun 1945 yang menegaskan, "Bumi, air, dan kekayaan alam yang terkandung didalamnya dikuasai oleh negara dan dipergunakan untuk sebesar-besarnya kemakmuran rakyat." Guna mencapai tujuan tersebut, salah satunya ditetapkan Undang-Undang Nomor 5 Tahun 1960 tentang Peraturan Dasar Pokok-Pokok Agraria, Lembaran Negara Republik Indonesia Tahun 1960 Nomor 104, Tambahan Lembaran Negara Republik Indonesia Nomor 2043 (selanjutnya disebut UUPA).

UUPA sebagai produk hukum agrarian nasional memiliki beberapa prinsip yang memberdakan dengan hukum agrarian kolonial ${ }^{3}$ yang berlaku sebelum tahun

\footnotetext{
${ }^{1}$ Sri Hajati,[et.,al.], Buku Ajar Politik hukum Pertanahan(2017).[1].

${ }^{2}$ Ibid.

${ }^{3}$ Ibid.
} 
1960, salah satunya adalah prinsip nasionalitas.Prinsip nasionalitas atau prinsip kebangsaan mengandung makna bahwa seluruh wilayah Indonesia adalah karunia Tuhan Yang Maha Esa, kesatuan tanah air dari bangsa Indonesia, kemerdekaanya diperjuangkan oleh bangsa Indonesia, sehingga menjadi hak dari bangsa Indonesia. ${ }^{4}$ Prinsip ini terkandung dalam Pasal 1 UUPA yang menegaskan:

(1) Seluruh wilayah Indonesia adalah kesatuan tanah air dari seluruh rakyat Indonesia yang bersatu sebagai bangsa Indonesia.

(2) Seluruh bumi, air dan ruang angkasa, termasuk kekayaan alam yang terkandung didalamnya dalam wilayah Republik Indonesia, sebagai karunia Tuhan Yang Maha Esa adalah bumi, air dan ruang angkasa bangsa Indonesia dan merupakan kekayaan nasional.

(3) Hubungan antara bangsa Indonesia dan bumi, air serta ruang angkasa termaksud dalam ayat (2) pasal ini adalah hubungan yang bersifat abadi.

Hubungan yang bersifat abadi sebagaimana ditentukan dalam Pasal 1 ayat (3) UUPA menegaskan bahwa selama bangsa Indonesia masih ada tidak ada hal apa pun yang dapat memutuskan hubungan bangsa Indonesia dengan tanah airnya. Sehingga dengan prinsipini ditentukan hanya warga negara Indonesia saja yang dapatmempunyai hak atas tanah atas dasar hak milik tanpa membedakan jenis kelamin laki-laki maupun perempuan, sementara bagi warga negara asing tidak akan memiliki hak milik serta pemindahan hak milik kepada orang asing, dilarang sebagaimana ditegaskan dalam Pasal 26 ayat (2) UUPA. ${ }^{5}$ Namun UUPA tidak menutup kemungkinan tidak dapat dimilikinya hak atas tanah oleh orang asing, karena terdapat pengecualian dapat dimilikinya hak atas tanah yang berstatus hak pakai.

Era globalisasi dan perdagangan bebas membuka kesempatan bagi seluruh negara untuk memperluas ruang gerak arus transaksi barang dan/atau jasa.Oleh karena itu keberadaan orang asing Indonesia adalah sesuatu yang niscaya misalnya adanya turis asing, pelajar asing, bahkan pekerja asing. Kementerian Tenaga Kerja mencatat, jumlah tenaga kerja asing (TKA) hingga saat ini mencapai 126 ribu

\footnotetext{
4 Ibid., [37]

5 Ibid.
} 
orang atau meningkat 69,85 persen dibandingkan akhir 2016 sebanyak 74.813 orang. ${ }^{6}$ Menteri Ketenagakerjaan Hanif Dhakiri menuturkan, selain berasal dari China, para pekerja asing juga banyak berasal dari Jepang, Amerika Serikat, dan Singapura.Kendati jumlahnya melesat, pemerintah masih berkeinginan untuk mempermudah masuknya TKA profesional yang masih dibutuhkan di sektorsektor tertentu. ${ }^{7}$ Keberadaan orang asing di Indonesia memberikan dampak hukum tersendiri, khususnya yang berkaitan dengan tanah karena keberadaan orang asing pasti membutuhkan tempat tinggal yang berdiri diatas tanah.Menjadi pertanyaan apakah kebijakan sistem hukum pertanahan Indonesia sudah siap menghadapi era globalisasi khususnya dalam hal penggunaan, penguasaan dan pemilikan hak atas tanah oleh orang asing karena jika tidak kemungkinan eksploitasi untuk kepentingan asing menjadi tidak dapat dihindarkan.

\section{Berdasarkan UUPA}

Dasar konstitusional politik hukum agrarian nasional Indonesia adalah Pasal 33 ayat (3) UUD Tahun 1945 yang menegaskan, "Bumi, air, dan kekayaan alam yang terkandung didalamnya dikuasai oleh negara dan dipergunakan untuk sebesar-besarnya kemakmuran rakyat.” Wewenang negara yang dinyatakan dalam Psal 33 ayat (3) UUD 1945 belum merupakan norma dalam arti sesungguhnya dan juga mempunyai sifat sebagai norma samar dan norma terbuka. ${ }^{8}$ Atas dasar hak menguasai negara tersebut Pasal 2 ayat (2) UUPA menegaskan makna terminologi “dikuasai oleh negara" antara lain:

a. Mengatur dan menyelenggarakan peruntukan penggunaan, penyediaan, dan pemeliharaan bumi, air, dan ruang angkasa.

b. Menentukan dan mengatur hubungan-hubungan hukum antara orang-orang

${ }^{6}$ Galih Gumelar, 'Jumlah Tenaga Kerja Asing Membludak, Mayoritas dari China' (CNN Indonesia, 2018), di akses pada tanggal 22 Agustus 2018 melalui:

<https://www.cnnindonesia.com/ekonomi/20180306201957-92-280945/jumlah-tenaga-kerja-asing-membludak-mayoritas-dari-china $>$

7 Ibid.

${ }^{8}$ Sri Hajati,[et all]., Op.Cit.,[53]. 
dengan bumi, air, dan ruang angkasa.

c. Menentukan dan mengatur hubungan-huubungan hukum antara oran-orang dan perbuatan-perbuatan hukum yang mengenai bumi, air, dan ruang angkasa.

Hak menguasai negara tersebut pada dasarnya memberikan wewenang kepada negara untuk mengatur dan menyelenggarakan peruntukan, penggunaan, persediaan, dan pemeiliharaan bumi, air, ruang angkasa dan kekayaan alam yang terkandung didalamnya sebesar-besarnya untuk kemakmuran rakyat.Menurut Iman Sutiknyo, hak menguasai negara memberikan wewenang kepada negara baik secara ke dalam maupun ke luar. ${ }^{9}$ Salah satu kewenangan negara ke dalam adalah menentukan adanya macam-macam hak atas permukaan bumi yang dapat diberikan kepada dan dipunyai oleh orang-orang baik sendiri maupun bersama-sama dengan orang lain serta badan hukum.

Ketentuan hukum mengenai hak atas tanah diatur dalam Pasal 4ayat (1) UUPA yang menegaskan, “Atas dasar hak menguasai dari negara atas tanahsebagaimana yang dimaksuddalam Pasal 2 ditentukanadanya macam-macam hak ataspermukaan bumi, yang disebuttanah, yang dapat diberikankepada dan dipunyai oleh orangorang, baik sendiri maupun bersama-sama denganorang-orang lain serta badanbadan hukum." Wewenang dalam hak atas tanah lebih lanjut ditegaskan dalam Pasal 4 ayat (2) UUPA, "Hak-hak atas tanah yang dimaksud dalam ayat 1 Pasal ini memberi wewenang untuk menggunakan tanah yang bersangkutan, demikian pula tubuh bimi dan air dan ruang yang ada diatasnya sekadar diperlukan untuk kepentingan yang langsung berhubungan dengan penggunaan tanah itu dalam batas-batas menurut undang-undang ini dan peraturan-peraturan hukum lain yang lebih tinggi."

Hak atas tanah pada dasarnyaadalah sebuah kewenangan untuk“memakai" suatu bidang tanah tertentu dalam memenuhi suatukebutuhan tertentu. ${ }^{10}$ Macam-

9 Ibid., [57] (dikutip dari Iman Sutiknyo,Politik Agararia Nasional: Hubungan Manusia dengan tanah yang Berdasarkan Pancasila(1990). [28]. Lihat pula Sri Hajati, 'Kewenangan Negara Atas Tanah'. Jurnal Yuridika, Vol. 18, No.2, Maret 2003, [168-169]).

${ }^{10}$ Mohammad Machfudh Zarqoni, Hak Atas Tanah (2015).[36]. 
macamhak atas tanah yang dimaksud dalam Pasal 4 UUPA diatursecara jelas di dalam Pasal 16ayat (1) UUPA yaitu hak milik, hak guna usaha, hak guna bangunan, hak pakai, hak sewa, hak membuka tanah, hak memungut hasil hutan, dan hak-hak lain yang tidak termasukdalam hak-hak tersebut di atasyang akan ditetapkan denganundang-undang serta hak-hak yangsifatnya sementara sebagai yangdisebutkan dalam Pasal 53 UUPA antara lain hak gadai, hak usaha bagi hasil, hak menumpang, dna hak sewa tanah pertanian.

Terhadap penggunaan, penguasaan dan pemilikan hak atas tanah oleh warga negara asing yang berkedudukan di Indonesia diatur dalam beberapa Pasal dalam UUPA, antara lain:

a. Pasal 21 UUPA menegaskan, “(1) Hanya warga negara Indonesia dapatmempunyai hak milik.(2) Oleh Pemerintah ditetapkan badanbadanhukum yang dapat mempunyaihak milik dan syarat-syaratnya.(3) Orang asing yang sesudah berlakunyaUndang-undang ini memperoleh hakmilik karena pewarisan tanpa wasiatatau percampuran harta karenaperkawinan, demikian pula warganegaraIndonesia yang mempunyai hakmilik dan setelah berlakunya Undang-undang ini kehilangan kewarganegaraannyawajib melepaskan hak itudidalam jangka waktu satu tahun sejakdiperolehnya hak tersebut atauhilangnya kewarganegaraan itu. Jikasesudah jangka waktu tersebut lampauhak milik itu dilepaskan, maka haktersebut hapus karena hukum dantanahnya jatuh pada Negara, denganketentuan bahwa hak-hak pihak lainyang membebaninya tetapberlangsung.(4) Selama seseorang disamping kewarganegaraanIndonesianya mempunyaikewarganegaraan asing maka ia tidakdapat mempunyai tanah dengan hakmilik dan baginya berlaku ketentuandalam ayat (3) pasal ini."

b. Pasal26UUPAmenegaskan, “(1)Jual-beli, penukaran, penghibahan,pemberian dengan wasiat, pemberianmenurut adat dan perbuatan-perbuatanlain yang. dimaksudkan untukmemindahkan hak milik sertapengawasannya diatur denganPeraturan Pemerintah.(2) Setiap jual beli, penukaran,penghibahan, pemberian dengan wasiatdan perbuatan-perbuatan lain yangdimaksudkan 
untuk langsung atau tidak langsung memindahkan hak milikkepada orang asing, kepada seorangwarga negara yang disampingkewarganegaraan Indonesianyamempunyai kewarganegaraan asingatau kepada suatu badan hukumkecuali yang ditetapkan olehPemerintah termaksud dalam pasal 21 ayat (2), adalah batal karena hukumdan tanahnya jatuh kepada negara,dengan ketentuan, bahwa hak-hakpihak lain yang membebaninya tetapberlangsung serta semua pembayaranyang telah diterima oleh pemilik tidakdapat dituntut kembali."

c. Pasal 42 UUPA menegaskan, "Yang dapat mempunyai hak pakai ialah:(1) Warga negara Indonesia; (2) Orang asing yang berkedudukan diIndonesia; (3) Badan hukum yang didirikan menuruthukum Indonesia dan berkedudukan diIndonesia; (4) Badan hukum asing yang mempunyaiperwakilan di Indonesia."

Berdasarkan ketentuan-ketentuan tersebut dapat disimpulkan bahwa hanya warga negara Indonesia yang berhak memiliki hak milik, pun warga negara asing telah memiliki sebelum adanya UUPA akibat perkawinan campuran maka diwajibkan untuk melepaskan haknya tersebut.Hak milik yang diperuntukan khusus warga negara Indonesia adalah sejalan dengan asas nasionalitas, karena hak milik adalah hak atas tanah yang memiliki ciri unggul yaitu terkuat (selama-lamanya), terpenuh (dapat menjadi dasar hak atas tanah lain, turun temurun, bahkan peruntukannya tak terbatas yaitu bisa untuk pertanian maupun non-pertanian.Sedangkan orang asing hanya berhak memiliki hak atas tanah dengan jenis hak pakai.Berdasarkan Pasal 41 ayat (1) UUPA, "Hak Pakai adalah hak untuk menggunakan dan/atau memungut hasil dari tanah yang dikuasai langsung oleh negara atau tanah milik orang lain, yang memberi wewenang dan kewajiban yang ditentukan dalam surat keputusan pemberiannya oleh pejabat yang berwenang memberikannya atau dalam perjanjian dengan pemilik tanahnya, yang bukan perjanjian sewa menyewa atau perjanjian pengolahan tanah, segala sesuatu asal tidak bertentangan dengan jiwa dan Ketentuanketentuan Undang-undang ini.” Berdasarkan pengertian tersebut, dijelaskan oleh Urip Santoso bahwa, "Perkataan "menggunakan” dalam Hak Pakai menunjuk pada 
pengertian bahwa hak pakai digunakan untuk kepentingan mendirikan bangunan, sedangkan perkataan "memungut hasil” dalam Hak Pakai menunjuk pada pengertian bahwa Hak Pakai digunakan untuk kepentingan selain mendirikan bangunan, misalnya pertanian, perikanan, peternakan dan perkebunan". ${ }^{11}$

\section{Berdasarkan Peraturan Pemerintah Nomor 40 Tahun 1996}

Pengaturan mengenai hak pakai lebih lanjut diatur dalam Peraturan Pemerintah Republik Indonesia Nomor 40 Tahun 1996 tentang Hak Guna Usaha, Hak Guna Bangunan dan Hak Pakai atas Tanah, Lembaran Negara Republik Indonesia Tahun 1996 Nomor 58, Tambahan Lembaran Negara Republik Indonesia Tahun 1996 Nomor 3643 (untuk selanjutnya disingkat PP No. 40 Tahun 1996). Pasal 39 PP No. 40 Tahun 1996 menegaskan mengenai batasan subyek hak pakai yang lebih luas daripada Pasal 42 UUPA yaitu warga negara Indonesia, badan hukum yang didirikan menurut hukum Indonesia dan berkedudukan di Indonesia, departemen, lembaga pemerintah non departemen, dan pemerintah daerah, badanbadan keagamaan dan sosial, orang asing yang berkedudukan di Indonesia, badan hukum asing yang mempunyai perwakilan di Indonesia, perwakilan negara asing dan perwakilan badan internasional.

Berdasarkan Pasal 41 jo. Pasal 42 jo. Pasal 44 PP No. 40 Tahun 1996, tanah yang dapat diberikan hak pakai adalah tanah negara yang diberikan dengan keputusan pemberian hak oleh Menteri atau pejabat yang ditunjuk, tanah hak pengelolaan yang diberikan dengan keputusan pemberian hak oleh Menteri atau pejabat yang ditunjuk berdasarkan usul pemegang hak pengelolaan, atau tanah hak milik yang terjadi dengan pemberian hak pakai oleh pemilik tanah hak milik dengan akta Pejabat Pembuat Akta Tanah. Jadi, alas hak yang dapat menjadi hak pakai diatur dalam PP No. 40 Tahun 1996 lebih luas daripada yang diatur dalam Pasal 41 ayat (1) UUPA.

PP No. 40 Tahun 1996 mengatur bahwa berdasarkan jangka waktu, hak pakai dapat dibedakan menjadi 2 (dua) yaitu:

${ }^{11}$ Urip Santoso, Hukum Agraria Kajian Komperhensif(2015).[119] 
a. Hak pakai yang berjangka waktu (bersifat privat)

1. Diberikan untuk jangka waktu yang tidak ditentukan terhadap hak pakai atas tanah negara selama tanahnya dipergunakan untuk keperluan tertentu, yang diberikan kepada departemen, lembaga pemerintah non departemen, pemerintah daerah, perwakilan negara asing, perwakilan badan internasional, dan badan-badan keagamaan dan sosial.

2. Diberikan untuk jangka waktu tertentu, yaitu:

a. Hak pakai atas tanah negara dan tanah hak pengelolaan diberikan untuk jangka waktu paling lama dua puluh lima tahun dan dapat diperpanjang untuk jangka waktu paling lama dua puluh tahun.

b. Hak Pakai atas tanah Hak Milik diberikan untuk jangka waktu paling lama dua puluh lima tahun dan tidak dapat diperpanjang. Atas kesepakatan antar pemegang Hak Pakai dengan pemegang Hak Milik, Hak Pakai atas tanah Hak Milik dapat diperbaharui dengan pemberian Hak Pakai baru dengan akta yang dibuat oleh Pejabat Pembuat Akta Tanah.

b. Hak pakai yang tidak berjangka waktu (bersifat publik)

Hak pakai ini hanya dimiliki oleh badan hukum publik dan hanya memiliki right to use, yaitu mempergunakannya untuk waktu yang tidak terbatas selama pelaksanaan tugas.Sedangkan right of dispossal tidak dimiliki karena tidak dapat dialihkan dalam bentuk apapun kepada pihak ketiga dan juga tidak dapat dijadikan obyek Hak Tanggungan. ${ }^{12}$

\section{Berdasarkan Peraturan Pemerintah Nomor 103 Tahun 2015}

Khusus hak pakai yang dapat dipunyai oleh orang asing yang berkedudukan di Indonesia untuk kepentingan rumah tempat tinggal atau hunian diatur dalam Peraturan Pemerintah Nomor 103 Tahun 2015 tentang Pemilikan Rumah Tempat Tinggal atau Hunian oleh Orang Asing yang Berkedudukan di Indonesia, Lembaran

${ }^{12}$ Ibid., [112] 
Negara Republik Indonesia Tahun 2015 Nomor 325, Tambahan Lembaran Negara Republik Indonesia Nomor 5793 (untuk selanjutnya disingkat PP No. 103 Tahun 2015). PP No. 103 Tahun 2015 tersebut mencabut dan menyatakan tidak berlaku Peraturan Pemerintah Nomor 41 Tahun 1996 tentang Pemilikan Rumah Tempat Tinggal atau Hunian oleh Orang Asing yang Berkedudukan di Indonesia.

Berdasarkan Pasal 1 ayat (1) PP No. 103 Tahun 2015, “Orang asing yang berkedudukan diIndonesia yang selanjutnya disebutOrang Asing adalah orang yang bukanWarga Negara Indonesia yangkeberadaanya memberikan manfaat,melakukan usaha, bekerja, atauberinvestasi di Indonesia.’Pasal 2 PP No. 103 Tahun 2015 mengatur lebih lanjut mengenai persyaratan mengenai orang asing yang dapat memiliki hak atas tanah di Indonesia yaitu hanyalah orang asing pemegang izin tinggal di Indonesia, baik izin tinggal diplomatik, izin tinggal dinas, izin tinggal kunjungan, izin tinggal terbatas maupun izin tinggal tetap. Bahkan terdapat ketentuan baru yang diatur yaitu apabila orang asing tersebut meninggal dunia, maka rumah tempat tinggal atau hunian dapat diwariskan kepada ahli waris yang juga memiliki izin tinggal di Indonesia. Apabila orang asing atau ahli waris yang merupakan orang asing yang memiliki rumah yang dibangun diatas tanah hak pakai atau berdasarkan perjanjian dengan pemegang hak atas tanah tidaklagiberkedudukan di indonesia, dalam jangka waktu 1 (satu) tahun wajib melepaskan atau mengalihkan hakatas rumah dan tanahnya kepada pihak lain yang memenuhi syarat.

Ditegaskan dalam Pasal 2 ayat (1) mengenai hak orang asing dapat memiliki hak atas tanah di Indonesia, "Orang Asing dapat memiliki rumah untuktempat tinggal atau hunian dengan HakPakai."Pasal 4 menegaskan bahwa, "Rumah tempat tinggal atau hunian yangdapat dimilikioleh Orang Asing sebagaimanadimaksud dalam Pasal 2 ayat (1) merupakan:

a. Rumah Tunggal ${ }^{13}$ di atas tanah:

1. Hak Pakai; atau

2. Hak Pakai di atas Hak Milik yangdikuasai berdasarkan perjanjianpemberian

${ }^{13}$ Rumah tunggal adalah rumah yangmempunyai kavling sendiri dan salahsatu dinding bangunan tidak dibanguntepat pada batas kavling 
Hak Pakai di atas Hak Milikdengan akta Pejabat Pembuat AktaTanah.

b. Satuan Rumah Susun ${ }^{14}$ (selanjutnyadisingkat sarusun) yang dibangun di atas bidangtanah Hak Pakai."

Mengenai jangka waktu ketentuan dalam Pasal 6 jo. Pasal 7 PP No. 103 Tahun 2015 cukup berbeda dengan pengaturan yang terdapat dalam PP No. 40 Tahun 1996 bahkan hak pakai tersebut dapat diperbaharui untuk jangka waktu tertentu.Dapat dijelaskan mengenai jangka waktu rumah tunggal bagi orang asing sebagai berikut:

1. Rumah tungal diatas tanah hak pakai atas tanah negara dan tanah hak pengelolaan diberikan untuk jangka waktu paling lama tiga puluh tahun, dapat diperpanjang untuk jangka waktu paling lama dua puluh tahun, serta dapat diperbaharui untuk jangka waktu tiga puluh tahun.

2. Rumah tungal diatas tanah hak pakai di atas tanah hak milik yang dikuasai berdasarkan perjanjian diberikan untuk jangka waktu yang disepakati tidak lebih dari tiga puluh tahun, dapat diperpanjang untuk jangka waktu paling lama dua puluh tahun sesuai kesepakatan, serta dapat diperbaharui untuk jangka waktu paling lama tiga puluh tahun sesuai kesepakatan dengan pemegang hak atas tanah.

\section{Berdasarkan Peraturan Menteri Agraria dan Tata Ruang/ Kepala Badan} Pertanahan Nasional Nomor 29 Tahun 2016 tentang Tata Cara Pemberian, Pelepasan, atau Pengalihan Hak Atas Pemilikan Rumah Tempat Tinggal atau Hunian oleh Orang Asing yang Berkedudukan di Indonesia

PP No. 103 Tahun 2015 dilaksanakan oleh Peraturan Menteri Agraria dan Tata Ruang/ Kepala Badan Pertanahan Nasional Nomor 29 Tahun 2016 tentang Tata Cara Pemberian, Pelepasan, atau Pengalihan Hak Atas Pemilikan Rumah Tempat Tinggal atau Hunian oleh Orang Asing yang Berkedudukan di Indonesia, yang ditetapkan pada tanggal 19 September 2016, Berita Negara Republik Indonesia Tahun 2016 Nomor 1442 (selanjutnya disingkat Permen ATR No. 29 Tahun 2016).

\footnotetext{
${ }^{14}$ Satuan rumah susun adalah unit rumah susunyang tujuan utamanya digunakan secaraterpisah dengan fungsi utama sebagaitempat hunian dan mempunyai sarana penghubung ke jalan umum.
} 
Permen ATR No. 29 Tahun 2016 bertujuan untuk memberikan kepastian hukum atas pemilikan rumah tempat tinggal oleh orang asing dan mencegah peralihan hak yang tidak sesuai dengan ketentuan peraturan perundang-undangan. Namun, terdapat ketentuan baru dalam Permen ATR No. 29 Tahun 2016, antara lain:

1. Ketentuan dalam Pasal 4 yang menegaskan bahwa rumah tempat tinggal atau hunian yang dapat dimiliki oleh orang asing merupakan:

a. Rumah tunggal, di atas tanah:

1. Hak pakai;

2. Hak pakai atas hak milik yang dikuasai berdasarkan perjanjian pemberian hak pakai di atas hak milik dengan akta pejabat pembuat akta tanah, yang diberikan untuk jangka waktu tiga puluh tahun, dan dapat diperpanjang untuk jangka waktu dua puluh tahun, serta dapat diperbaharui untuk jangka waktu tiga puluh tahun.

3. Hak pakai yang berasal dari perubahan hak milik atau hak guna bangunan, yang diberikan untuk jangka waktu selama sisa jangka waktu berlakunya hak guna bangunan dimaksud dan dapat diperpanjang untuk jangka waktu dua puluh tahun, serta dapat diperbaharui untuk jangka waktu tiga puluh tahun.

b. Satuan rumah susun yang:

1. Dibangun di atas bidang tanah hak pakai, yang diberikan untuk jangka waktu tiga puluh tahun, dan dapat diperpanjang untuk jangka waktu dua puluh tahun, serta dapat diperbaharui untuk jangka waktu tiga puluh tahun.

2. Berasal dari perubahan hak milik atas satuan rumah susun yang diberikan dengan jangka waktu selama sisa jangka waktu berlakunya hak milik atas satuan rumah susun dimaksud.

2. Rumah tempat tinggal atau hunian sebagaimana dimaksud dalam Pasal 4 diberikan dengan batasan harga minimal yang berbeda-beda batas minimalnya tergantung lokasi sebagaimana terdapat dalam lampiran Permen ATR No. 29 
Tahun 2016 dan terdapat persyaratan untuk rumah tinggal wajib: ${ }^{15}$

a. 1 (satu) bidang tanah per orang/keluarga; dan

b. Tanahnya paling luas 2.000 (dua ribu) meter persegi. ${ }^{16}$

\section{Perbandingan dengan Negara Lain}

Guna perbandingan hukum akan dijelaskan mengenai pengaturan kepemilikan hak atas tanah oleh orang asing di beberapan negara ASEAN, antara lain:

1. Cambodia dan Myanmar melarang kepemilikan hak atas tanah oleh orang asing secara mutlak. ${ }^{17}$

2. Laos hanya memperbolehkan penggunaan hak pakai oleh orang asing dengan syarat sebagai berikut: ${ }^{18}$
a. Registered Capital Requirements of USD 500,000 (persyaratan modal senilai500,000 dolar);
b. Land not more than 800 sq. meters (tanah tidak lebih 800 meter persegi);
c. For residential or business purposes (untuk tujuan perumahan atau bisnis); dan
d. Authorized to hold land use rights (termasuk subyek yang berhak).

3. Malaysia memperbolehkan kepemilikan hak atas tanah oleh orang asing dengan syarat sebagai berikut: ${ }^{19}$
a. State authority's approval (mendapat persetujuan);
b. Equity and paid up conditions if FDI restrictions are triggered; dan
c. Levy and moratorium depending on location of the land (membayar pungutan dan moratorium bergantung pada lokasi).

4. Thailand memperbolehkan kepemilikan hak atas tanah oleh orang asing dengan syarat sebagai berikut: ${ }^{20}$

\footnotetext{
${ }^{15}$ Tidak berlaku bagi pemilikan rumah tempat tinggal atau hunian oleh perwakilan negara asing dan/atau perwakilan badan internasional.

${ }^{16}$ Kecuali dalam keadaan tertentu yang mempunyai dampak positif luar biasa terhadap ekonomi, maka pemberian rumah tempat tinggal dapat diberikan dengan luas lebih dari 2.000 (dua ribu) meter persegi, dengan izin Menteri

${ }^{17}$ ZICO Law, 'Land Ownership in ASEAN' (ASEAN Insiders Series, March 2017) <URL address $>$, diakses pada dd-mm-yyyy.

${ }^{18}$ Ibid.

${ }^{19} \mathrm{Ibid}$.

${ }^{20}$ Ibid.
} 
a. Land must be utilized within one year of obtaining title (harus digunakan dalam waktu satu tahun).

b. for lands obtained through specific legislation (eg: Investment Promotion Law), land must be sold or transferred within 1 year of end of promotion period (tanah yang diperoleh dari undang-undang khusus misalnya undang-undang investasi harus dijual atau dialihkan dalam waktu 1 tahun).

5. Vietnam memperbolehkan kepemilikan hak atas tanah oleh orang asing dengan syarat penggunaan tanah hanya untuk proyek investasi di Vietnam. ${ }^{21}$

\section{Kesimpulan}

Berdasarkan pembahasan yang telah diuraikan dapat disimpulkan:

1. Pengaturan mengenai hak orang asing untuk memiliki hak atas tanah di Indonesia diatur secara khusus dalam PP No. 105 Tahun 2015 jo. Permen ATR No. 29 Tahun 2016, berdasarkan asas lex specialis derogate legi generali maka segala ketentuan mengenai hak pakai dalam PP No. 40 Tahun 1996 yang telah diatur dalam PP No. 105 Tahun 2015 adalah tidak berlaku.

2. Menjadi permasalahan sosial karena terdapat perbedaan terhadap pemilikan hak pakai oleh warga negara Indonesia yang berpedoman pada PP No. 40 Tahun 1996 dan hak pakai oleh orang asing yang berpedoman padal PP No. 105 Tahun 2015. Karena berdasarkan PP No. 40 Tahun 1996 hak pakai tidak dapat diwariskan, tidak dapat diperbaharui, dan jangka waktunya paling lama dua puluh lima tahun dan dapat diperpanjang untuk jangka waktu dua puluh lima tahun.

3. Adanya pembatasan yang diatur dalam Permen ATR No. 29 Tahun 2016 mengenai pembatasan harga, luasan, dan jumlah adalah upaya preventif yang patut diapresiasi karena dimaksudkan untuk mencegah penguasaan skala besar oleh orang asing.

${ }^{21}$ Ibid. 
4. Pengaturan negara lain mengenai hak orang asing untuk memperoleh hak atas tanah beberapa memiliki kesamaan yaitu diperkenankannya pemilikan dengan persyaratan-persyaratan tertentu seperti jumlah, syarat modal, harga, luas, maupun jangka waktu.

\section{Daftar Bacaan}

\section{Buku}

Mohammad Machfudh Zarqoni, Hak Atas Tanah (Prestasi Pustakaraya 2015).

Urip Santoso, Hukum Agraria Kajian Komperhensif(Pramedia Grup 2015).

Sri Hajati,[et.,al.], Buku Ajar Politik hukum Pertanahan (Airlangga University Press 2017).

ZICO Law, 'Land Ownership in ASEAN', (2017) ASEAN Insiders Series March.

Galih Gumelar, 'Jumlah Tenaga Kerja Asing Membludak, Mayoritas dari China' (CNNIndonesia, 2018), diakses pada tanggal22 Agustus 2018melalui: $<$ https:// www.cnnindonesia.com/ekonomi/20180306201957-92-280945/jumlahtenaga-kerja-asing-membludak-mayoritas-dari-china>

\section{Perundang-undangan}

Undang-Undang Dasar Negara Republik Indonesia Tahun 1945.

Undang-Undang Nomor 5 Tahun 1960 tentang Peraturan Dasar Pokok-Pokok Agraria (Lembaran Negara Republik Indonesia Tahun 1960 Nomor 104, Tambahan Lembaran Negara Republik Indonesia Nomor 2043).

Peraturan Pemerintah Republik Indonesia Nomor 40 Tahun 1996 tentang Hak Guna Usaha, Hak Guna Bangunan dan Hak Pakai atas Tanah (Lembaran Negara Republik Indonesia Tahun 1996 Nomor 58, Tambahan Lembaran Negara Republik Indonesia Tahun 1996 Nomor 3643).

Peraturan Pemerintah Nomor 103 Tahun 2015 tentang Pemilikan Rumah Tempat Tinggal atau Hunian oleh Orang Asing yang Berkedudukan di Indonesia (Lembaran Negara Republik Indonesia Tahun 2015 Nomor 325, Tambahan Lembaran Negara Republik Indonesia Nomor 5793).

Peraturan Menteri Agraria dan Tata Ruang/ Kepala Badan Pertanahan Nasional Nomor 29 Tahun 2016 tentang Tata Cara Pemberian, Pelepasan, atau 
Pengalihan Hak Atas Pemilikan Rumah Tempat Tinggal atau Hunian oleh Orang Asing yang Berkedudukan di Indonesia (ditetapkan pada tanggal 19 September 2016, Berita Negara Republik Indonesia Tahun 2016 Nomor 1442)

HOW TO CITE: Noer Sida, 'Kebijakan Hak Atas Tanah Untuk Rumah Tinggal Bagi Orang Asing’ (2018) Vol. 1 No. 2 Notaire. 